\title{
Antibacterial Activity of Twenty Different Endophytic Fungi Isolated from Calotropis procera and Time Kill Assay
}

\section{Reena Rani, Dushyant Sharma, Monika Chaturvedi and Jaya Parkash Yadav}

Department of Genetics, Maharshi Dayanand University, Rohtak, Haryana-124001, India

*Corresponding author: Jaya Parkash Yadav, Department of Genetics, Maharshi Dayanand University, Rohtak, Haryana-124001, India, Tel: +91-9416474640; Fax: 9416474640 E-mail: yadav1964@rediffmail.com

Received date: April 27, 2017; Accepted date: May 19, 2017; Published date: May 29, 2017

Copyright: @ 2017 Rani R, et al. This is an open-access article distributed under the terms of the Creative Commons Attribution License, which permits unrestricted use, distribution, and reproduction in any medium, provided the original author and source are credited.

\begin{abstract}
Background: Development of drug resistance in bacteria is a common and alarming problem worldwide and there is continuous and urgent need of antibacterial agents. Endophytes offer a plethora of secondary metabolites with various biological activities. These secondary metabolites may help the host plant in defense from pathogens and insects, growth stimulators also helps the host plant in stress tolerance. Calotropis procera is a well-known medicinal plant, used to cure various health ailments traditionally. So, the endophytic fungi isolated from different tissues (leaf, stem and root) of $C$. procera were evaluated for their antibacterial potential.
\end{abstract}

Methods: The antibacterial activity of crude ethyl acetate extracts of 20 different endophytic fungi was evaluated by using agar well diffusion assay against total nine bacterial reference strains. Minimum inhibitory concentration was determined by using microbroth dilution method. Time kill assay study was performed against the Salmonella typhi bacterial strain by using Aspergillus nomius extract.

Results: Out of the total 20 different endophytic fungal strains 7 endophytic fungal extracts showed activity against all tested bacterial strains. The endophytic fungi which belong to Aspergillus and Fusarium genus exhibited good antibacterial activity. Maximum zone of inhibition $(17.33 \mathrm{~mm})$ was shown by extracts of Aspergillus nomius, Fusarium solani, Aspergillus oryzae and Curvularia hawaiiensis against S. typhi, S. flexneri, S. typhi and S. marcescens respectively. Extracts of Aspergillus nidulans, Curvularia hawaiiensis, Chaetomium arcuatum and Chaetomium atrobrunneum also exhibited significant antibacterial activity against the tested bacterial strains. The MIC values were ranged between $15.6 \mu \mathrm{g} /$ well to $250 \mu \mathrm{g} /$ well. The endophytic fungal extracts were more efficient against the growth of Gram-positive bacteria as compared to Gram-negative. Time kill assay study against the $S$. typhi showed bacteriostatic effect of Aspergillus nomius strain extract at different concentrations.

Conclusion: Several endophytic fungi inhabit the different tissues of $C$. procera have capability of producing bioactive secondary metabolites with significant antibacterial activity. Further isolation and identification of these secondary metabolites may provide a new lead for development of novel drug molecules.

Keywords: Endophytic fungi; Calotropis procera; Antibacterial activity; Minimum inhibitory concentration (MIC); Time kill assay; Aspergillus, Fusarium

\section{Introduction}

The emergence of resistance in pathogenic bacteria to the commercial antibiotics is a very common and alarming problem around the world. In addition to intrinsic capacity of bacteria to develop resistance against the drugs, many other extrinsic factors favour this situation [1]. These extrinsic factors mainly include the improper and extensive use of antibiotics, immigration, emigration, lack of proper or late diagnosis of infection and others. As a result, there is a continuous need for novel and effective antimicrobial agents. In order to isolates the new drug molecules, endophytic fungi provide a unique niche because these are less evaluated as compare to sand fungi.

Schulz et al. [2] indicates that about $51 \%$ of biologically active molecules isolated from endophytic fungi were previously unidentified. So, there has been a tremendous increase in interest to explore the endophytes for their diversity, ecological role, secondary metabolites and bioactivity.

Endophytes are the organisms which are in an imperceptible relationship with the plant in which they reside for their whole lifetime or a part of their life [3]. These include fungi, bacteria and some algae [4]. They colonize all the plants evaluated till now and isolated from almost all the plant parts like leaves, roots, stems, flowers, barks and even from dry seeds [5].

Endophytic fungi have a capacity to produce diverse class of plant associated secondary metabolites with a wide variety of biological activities such as taxol (anticancer) [6], rohitukine (anticancer) [7], antimicrobial agent hypericin [8] and acetylcholinesterase inhibitor huperzine A [9].

Plants used in the traditional medicine have offered a very important habitat to isolate the strains the endophytic fungi which produce new bioactive compounds. Many studies suggested that the medicinal properties of a plant may be due to the metabolites produce by their endophytic microorganisms [10]. Despite this fact, a large number of medicinal plants yet to be studied for the presence of 
endophytes and their bioactivity like Calotropis procera. C. procera is a well-known medicinal plant belongs to family Apocynaceae, native to Asia and tropical Africa. [11].

C. procera has been used in traditional medicinal system with a number of properties like antimicrobial [12], analgesic, antiinflammatory, antidiabetic, cytotoxic, anticancerous, dyspepsia and hepatoprotective effects [13]. Its root bark is used for treatment of skin related anomalies. The secretion from the root bark is traditionally used for the treatment of skin diseases, enlargements of abdominal viscera and snakebite, and for intestinal worms problems [14]. Previous research showed that procerin, a compound isolated from $C$. procera displayed remarkable antimicrobial, insecticidal, proteolytic activities while proceragenin, calotoxin, hydroxyketone showed significant cytotoxic and anti-helmintic activity [15]. Previous studies reported that certain endophytic fungi produce secondary metabolites especially those that are exclusively synthesized by their host plants $[16,17]$.

The aim of the present work was to obtain crude extracts of fungal endophytes isolated from different tissues of $C$. procera and investigate their antibacterial activity against the reference strains along with time kill kinetic study.

\section{Materials and Methods}

Plant parts were collected, identified and authenticated by comparing the herbarium specimen available in the Department of Genetics, M. D. University, Rohtak (Voucher no. MDU 4602).

\section{Isolation of endophytic fungi}

Plants have endophytes as well as epiphytes associated with them. So, for the isolation of endophytic fungi plant tissues were first surface sterilized to remove any associated epiphytes [18]. Healthy tissues of $C$. procera were washed with running tap water. The plant tissues were sterilized by dipping into the $70 \%$ ethanol for $1 \mathrm{~min}$ followed by immersion in sodium hypochlorite $(4 \% \mathrm{w} / \mathrm{v}$ solution of available chlorine, Merck, India) for $4 \mathrm{~min}$; in $75 \%$ ethanol for $45 \mathrm{sec}$. Tissues were washed thrice with the sterile distilled water.

The efficiency of sterilization was checked by incubating last rinse water of the plant tissues on to the Petri dishes containing potato dextrose agar (PDA) medium, pH $5.6 \pm 0.2$. Sterilized plants tissues were cut into small pieces and incubated over PDA containing Petri dishes supplemented with streptomycin (100 mg/L, Himedia) to prevent the growth of endophytic bacteria. The Petri dishes were incubated at $28 \pm 2^{\circ} \mathrm{C}$ in incubator. Plates were observed continuously for the growth of endophytic fungi. The tips of fungal mycelia were continuously transferred on fresh media till the isolation of pure culture. A total of 20 actively growing endophytic fungi were molecularly identified by using ITS1 and ITS4 primer pair and sequences were deposited in NCBI (data is unpublished yet).

\section{Preparation of crude fungal extracts}

For preparation of crude fungal extracts the endophytic fungi were incubated by inoculating fungal mycelia in culture media contained potato dextrose broth (PDB) media for 10-15 days at $28 \pm 2{ }^{\circ} \mathrm{C}$ on an incubator shaker at $140 \mathrm{rpm}$. Fungal mycelia were separated by using Whatman filter paper. Filtrate was transferred to a big separating funnel to which approximate same volume of ethyl acetate was added. The separating funnel was strongly stirred up and left for an hour.
A clear boundary was formed on behalf of polarity in between upper phase contained secondary metabolites dissolved in ethyl acetate and lower phase contained media. Ethyl acetate phase containing secondary metabolites was collected and concentrated in rotary evaporator. Fungal mycelia obtained after filtration was also subjected for extraction by using cold percolation method with the ethyl acetate. Extracts obtained after evaporation were stored at $40^{\circ} \mathrm{C}$ until use.

\section{Assessment of antibacterial activity}

Tested microorganisms: The crude extracts of endophytic fungi were tested for their antibacterial potential against total 9 American Type Culture Collection (ATCC) reference bacterial strains. Among them two strains were Gram-positive: Enterococcus faecalis (ATCC 29212) and Staphylococcus aureus (ATCC 259323) and 7 strains were Gramnegative includes Pseudomonas aeruginosa (ATCC 27853), Serratia marcescens (ATCC 27137), Shigella flexneri (ATCC 12022), Salmonella typhi (ATCC 13311) Escherichia coli (ATCC 25922), Proteus mirabilis (ATCC 43071) and Klebsiella pneumoniae (ATCC 700603). Bacteria previously stored at $4^{\circ} \mathrm{C}$ were freshly streak on nutrient agar medium and incubated at $35^{\circ} \mathrm{C}$ for 24 hours. After incubation, bacteria were suspended in sterile peptone water to obtained standard inoculums of approximately $5 \times 10^{8} \mathrm{CFU} / \mathrm{ml}$ equivalents to $0.5 \mathrm{McF}$ arland units.

Antibacterial activity: The antibacterial activity of crude endophytic fungal was determined using the agar well diffusion method as described by Taye et al. [19]. Fresh bacterial inoculums $(100 \mu \mathrm{L})$ prepared in peptone water were uniformly spread over Petri dishes containing nutrient agar medium using sterile spreader. Wells of $6 \mathrm{~mm}$ were made with the help of a sterile borer. Stock solution of different endophytic fungal extracts was prepared at a concentration of 100 $\mathrm{mg} / \mathrm{ml}$ of DMSO (1/10 $0^{\text {th }}$ diluted). A volume of $40 \mu \mathrm{l}$ of each extracts was added to each well for all bacterial strains tested. Streptomycin (HiMedia laboratories Pvt. Ltd. India, $10 \mu \mathrm{g} / \mathrm{disc}$ ) was used as positive control. DMSO $\left(1 / 10^{\text {th }}\right.$ diluted) used as negative control. Zone of inhibition of fungal extracts around each well was measured with the help of a standard transparent scale HiAntibiotic ZoneScaleTM-C (HiMedia Laboratories Pvt. Ltd. India).

Minimum inhibitory concentration (MIC): Minimum inhibitory concentration (MIC) is the measure to check the growth of bacterial growth after $24 \mathrm{~h}$ of incubation on lowest concentration of an antibacterial agent. MIC values for different extracts of endophytic fungi were determined using microbroth dilution method of Sarker et al. [20] in 96 well microtitre plates. $50 \mu$ of sterile nutrient broth and $50 \mu$ of normal saline were added to each well of microtitre plate followed by the addition of $100 \mu \mathrm{l}$ of fungal extract in DMSO (stock solution $100 \mathrm{mg} / \mathrm{ml}$ dissolved in $1 / 10^{\text {th }}$ diluted DMSO) in the first row of the microtitre plate. Serial dilutions were performed in a way that first row had highest concentration and the last row had lowest concentration of endophytic fungal extracts. A volume of $10 \mu \mathrm{l}$ of resazurin dye solution (HiMedia laboratories Pvt. Ltd.) was used as indicator (prepared by dissolving $270 \mathrm{mg}$ resazurin in $40 \mathrm{ml}$ of sterile distilled water) was also added to each well. Finally $10 \mu \mathrm{l}$ of bacterial inoculums with $5 \times 10^{8} \mathrm{CFU} / \mathrm{ml}$ was added to each well. Each plate had a first column with streptomycin positive control and second column with $1 / 10^{\text {th }}$ diluted DMSO used as negative control. Plates were wrapped in cling film to prevent dehydration of bacteria. The plates were incubated at $37^{\circ} \mathrm{C}$ for $24 \mathrm{~h}$ in an incubator. Change of colour from purple to pink or to colourless indicates the growth of 
Citation: $\quad$ Rani R, Sharma D, Chaturvedi M, Yadav JP (2017) Antibacterial Activity of Twenty Different Endophytic Fungi Isolated from Calotropis procera and Time Kill Assay. Clin Microbiol 6: 280. doi:10.4172/2327-5073.1000280

Page 3 of 6

bacteria. The lowest concentration at which no color change observed was considered as the MIC value of that extract.

Time kill assay: Time kill assay was performed against the $S$. typhi using extract of Aspergillus nomius using method of Yadav et al. [21]. S. typhi was grown on PDA media on Petri dish. Individual colony of bacterium was isolated from $24 \mathrm{~h}$ old culture and suspended in sterile normal saline. Density of bacterial culture was adjusted to a 0.5 McFarland standard. This suspension was diluted 1:10 time in nutrient broth. For this $100 \mu \mathrm{l}$ of bacterial suspension was added into the $900 \mu \mathrm{L}$ of nutrient broth. Aspergillus nomius extracts were prepared at concentration of $1 / 2$ MIC, MIC and $2 \times$ MIC $(1 \mathrm{ml})$. Above prepared bacterial suspension was added to the extracts and incubated at $28 \pm$ $2^{\circ} \mathrm{C}$ for $24 \mathrm{~h}$. Positive control includes the bacterial suspension without endophytic fungal extracts and the negative control includes endophytic fungal extracts without bacterial inoculums. A volume of $25 \mu \mathrm{l}$ of sample was pipette out from each tube and spreaded over freshly prepared nutrient agar Petri dishes at 0, 2, 4, 6, 8 and $24 \mathrm{~h}$. Petri plates were incubated at $28 \pm 2^{\circ} \mathrm{C}$ for $24 \mathrm{~h}$ in an incubator. Colonies on individual plates were counted and expressed as number of colony forming units $/ \mathrm{ml}(\mathrm{CFU} / \mathrm{ml})$. The killing rate was determined by plotting logarithm of the viable colony counts $(\mathrm{CFU} / \mathrm{ml})$ against time. The percentage reduction in total viable count of CFU was counted by using the formula:

$$
\text { Percentage reduction }=\frac{\text { Initial count }- \text { count at } x \text { interval }}{\text { initial count }} \times 100
$$

\section{Statistical analysis}

All experiments were performed in triplicates. Results are represented as mean \pm standard deviation (SD).

\begin{tabular}{|c|c|c|c|c|c|c|c|c|c|}
\hline Name of fungus strains & E. coli & $\begin{array}{l}\text { K. } \\
\text { pneumonia }\end{array}$ & S. aureus & $P$. aeruginosa & S. typhi & $\begin{array}{l}\text { S. } \\
\text { marcescens }\end{array}$ & S. flexneri & E. Faecalis & P. mirabilis \\
\hline Chaetomium arcuatum & - & $14 \pm 1.00$ & $15 \pm 1.00$ & - & $17 \pm 1.00$ & $17 \pm 1.00$ & $17 \pm 1.00$ & $14.66 \pm 0.58$ & - \\
\hline Chaetomium sp. & $12 \pm 1.00$ & $13.66 \pm 0.58$ & $13.66 \pm 0.58$ & - & $16 \pm 1.00$ & $16 \pm 1.00$ & $16 \pm 1.00$ & $15 \pm 1.00$ & $14.66 \pm 0.58$ \\
\hline $\begin{array}{l}\text { Chaetomium } \\
\text { atrobrunneum }\end{array}$ & $11 \pm 1.00$ & $16 \pm 1.00$ & $16 \pm 1.00$ & - & $17 \pm 1.00$ & - & $16 \pm 1.00$ & $15 \pm 1.00$ & $13.66 \pm 1.15$ \\
\hline Penicillium crustosum & - & $13.66 \pm 0.58$ & $14.33 \pm 0.58$ & $11.33 \pm 0.58$ & $13.66 \pm 0.58$ & $13 \pm 1.00$ & $14.33 \pm 058$ & $15 \pm 1.00$ & $12 \pm 1.00$ \\
\hline Penicillium citrinum & - & $11 \pm 1.00$ & $15 \pm 1.00$ & $12 \pm 1.00$ & $12.66 \pm 0.58$ & $11.66 \pm 0.58$ & $13 \pm 1.00$ & $17 \pm 1.00$ & $15 \pm 1.00$ \\
\hline $\begin{array}{l}\text { Fusarium } \\
\text { chlamydosporum }\end{array}$ & $8.66 \pm 0.57$ & $13.66 \pm 0.58$ & $16.33 \pm 0.58$ & $11 \pm 1.00$ & $14 \pm 1.00$ & $16 \pm 1.00$ & - & - & - \\
\hline Fusarium graminearum & $11.66 \pm 0.58$ & $14 \pm 1.00$ & $13 \pm 1.00$ & $8.66 \pm 1.15$ & - & $15.66 \pm 0.58$ & $14.66 \pm 0.58$ & $13.66 \pm 0.58$ & $14.33 \pm 1.15$ \\
\hline Fusarium solani & - & - & $15.66 \pm 0.58$ & $11 \pm 1.00$ & - & $16 \pm 1.00$ & $17.33 \pm 0.58$ & $15.66 \pm 0.58$ & - \\
\hline Fusarium thapsinum & - & $15.66 \pm 0.58$ & $14.66 \pm 0.58$ & $11 \pm 1.00$ & $16 \pm 1.00$ & $14.66 \pm 0.58$ & $15 \pm 1.00$ & $15 \pm 1.00$ & $12 \pm 1.00$ \\
\hline Fusarium delphinoides & - & $10 \pm 1$ & $13 \pm 1$ & $12.33 \pm 0.52$ & $14.33 \pm 0.58$ & $12.66 \pm 0.58$ & $13 \pm 1$ & $8 \pm 1$ & - \\
\hline Aspergillus nomius & $11.66 \pm 0.33$ & $15 \pm 1.00$ & $14.66 \pm 0.58$ & $13.66 \pm 0.58$ & $17.33 \pm 0.52$ & $16 \pm 1.00$ & $16 \pm 1.00$ & $15 \pm 1.00$ & $14.66 \pm 1.15$ \\
\hline Aspergillus oryzae & $12 \pm 1.00$ & $16 \pm 1.00$ & $14.66 \pm 0.58$ & $14 \pm 1.00$ & $17.33 \pm 0.52$ & - & $14.66 \pm 0.58$ & $15 \pm 1.00$ & $15 \pm 1.00$ \\
\hline Aspergillus niger & $12.66 \pm 0.58$ & $16 \pm 1.00$ & $15.66 \pm 0.57$ & $14.66 \pm 058$ & $15.66 \pm 0.58$ & $17 \pm 1.00$ & $14.66 \pm 0.58$ & $15 \pm 1$ & $15 \pm 1$ \\
\hline Aspergillus terrus & $10 \pm 1.00$ & $15 \pm 1.00$ & $15 \pm 1.00$ & $13 \pm 1.00$ & $15 \pm 1.00$ & $15 \pm 1.00$ & $14.66 \pm 0.58$ & $15.66 \pm 0.58$ & $12.66 \pm 0.58$ \\
\hline Aspergillus nidulans & $11.33 \pm 1.52$ & $17 \pm 1.00$ & $14 \pm 1.00$ & $13.66 \pm 0.58$ & $17 \pm 1.00$ & $15 \pm 1.00$ & $16.66 \pm 0.58$ & $17.33 \pm 0.58$ & $15.33 \pm 1.15$ \\
\hline Candida blankii & $10.66 \pm 0.58$ & $12 \pm 1.00$ & $13 \pm 1.00$ & $12 \pm 1.00$ & $11 \pm 1.00$ & $13 \pm 1.00$ & $12.33 \pm 0.58$ & $13 \pm 1.00$ & $11 \pm 1.00$ \\
\hline Curvularia hawaiiensis & $9 \pm 1.00$ & $13.33 \pm 0.58$ & $13.67 \pm 0.58$ & $9.67 \pm 0.58$ & $14.33 \pm 0.58$ & $17.33 \pm 0.58$ & $14 \pm 1.00$ & $14.33 \pm 0.58$ & $14.33 \pm 0.58$ \\
\hline Cochliobolus hawaiiensis & $11 \pm 1.00$ & $17 \pm 1.00$ & $16 \pm 1.00$ &.- & $15 \pm 1.00$ & $13.66 \pm 0.58$ & $13.66 \pm 0.58$ & $12.33 \pm 0.2$ & - \\
\hline Alternaria alternata & $8 \pm 1.00$ & $15.33 \pm 1.52$ & $15 \pm 1.00$ & $11.33 \pm 0.52$ & $15.66 \pm 0.58$ & $14.66 \pm 0.58$ & $15 \pm 1.00$ & $13 \pm 1.00$ & $14 \pm 1.00$ \\
\hline Mucor circinelloides & - & $11 \pm 1.00$ & $12 \pm 1.00$ & - & $13.33 \pm 0.57$ & $13 \pm 1.00$ & $12.33 \pm 0.57$ & $13.66 \pm 0.57$ & - \\
\hline Control & $32.44 \pm 46$ & $29.44 \pm 0.44$ & $34.46 \pm 0.44$ & $29.46 \pm 0.36$ & $32 \pm 0.42$ & $33.46 \pm 0.44$ & $33.34 \pm 0.43$ & $32.58 \pm 0.40$ & $31.42 \pm 0.48$ \\
\hline
\end{tabular}

Table 1: Zone of inhibition of endophytic fungi isolated from C. procera against different tested strains in $\mathrm{mm}$. 
Citation: $\quad$ Rani R, Sharma D, Chaturvedi M, Yadav JP (2017) Antibacterial Activity of Twenty Different Endophytic Fungi Isolated from Calotropis procera and Time Kill Assay. Clin Microbiol 6: 280. doi:10.4172/2327-5073.1000280

Page 4 of 6

\section{Results}

\section{Antibacterial activity}

In the present study, total 20 different endophytic fungi crude ethyl acetate extracts were screened for their antibacterial potential. The antibacterial activity of fungal extracts was determined by measuring zone of inhibition and MIC values against 9 tested bacterial strains. The zones of inhibition against the bacterial strains are represented in Table 1. The diameter of inhibition zones was ranged from $8 \mathrm{~mm}$ to $17.33 \mathrm{~mm}$. Out of 20 endophytic fungi, 7 fungi exhibited antibacterial activity against the all tested bacterial strains. 6 endophytic fungi showed activity against 8 tested bacterial strains. Maximum zone of inhibition $(17.33 \mathrm{~mm})$ was shown by Aspergillus nomius, Fusarium solani, Aspergillus oryzae and Curvularia hawaiiensis against S. typhi, $S$. flexneri, $S$. typhi and $S$. marcescens respectively. Extracts of
Aspergillus nidulans, Curvularia hawaiiensis, Chaetomium arcuatum and Chaetomium atrobrunneum also exhibited significant activity against the tested bacterial strains. Minimum zone of inhibition (8 $\mathrm{mm}$ ) was exhibited by Fusarium delphinoides against E. faecalis, Fusarium chlamydosporum and Alternaria alternata against E. coli. The extract of Aspergillus nomius was most effective in inhibiting the growth of bacteria. Mucor circinelloides, Fusarium delphinoides were least active because they showed smaller zone of inhibition comparative to the others. Among the tested bacterial strains, E. coli was less susceptible to the fungal extracts and $S$. aureus found to be most susceptible bacterial strain inhibited by all tested endophytic fungal extracts. In context to Gram- positive and Gram-negative bacteria, Gram-positive bacteria were more susceptible to the fungal extracts. The MIC values for the fungal extracts against all the tested bacteria are represented in Table 2 . The MIC values ranged in between $15.6 \mu \mathrm{g} / \mathrm{well}$ to $250 \mu \mathrm{g} / \mathrm{well}$.

\begin{tabular}{|c|c|c|c|c|c|c|c|c|c|}
\hline Name of fungus strains & E. coli & K. pneumonia & S. aureus & $P$. aeruginosa & S. typhi & S. marcescens & S. flexneri & E. faecalis & P. mirabilis \\
\hline Chaetomium arcuatum & 250 & 31.2 & 31.2 & 250 & 15.6 & 15.6 & 15.6 & 31.2 & 250 \\
\hline Chaetomium sp. & 62.5 & 62.5 & 62.5 & 250 & 15.6 & 15.6 & 15.6 & 31.2 & 31.2 \\
\hline Chaetomium atrobrunneum & 62.5 & 15.6 & 15.6 & 250 & 15.6 & 250 & 15.6 & 31.2 & 62.5 \\
\hline Penicillium crustosum & 250 & 62.5 & 31.2 & 62.5 & 31.2 & 62.5 & 31.2 & 31.2 & 62.5 \\
\hline Penicillium citrinum & 250 & 62.5 & 31.2 & 62.5 & 62.5 & 31.2 & 62.5 & 31.2 & 31.2 \\
\hline Fusarium chlamydosporum & 125 & 62.5 & 15.6 & 62.5 & 31.2 & 15.6 & 250 & 250 & 250 \\
\hline Fusarium graminearum & 62.5 & 31.2 & 62.5 & 125 & 250 & 31.2 & 31.2 & 62.5 & 31.2 \\
\hline Fusarium solani & 250 & 250 & 31.2 & 62.5 & 250 & 62.5 & 15.6 & 31.2 & 250 \\
\hline Fusarium thapsinum & 250 & 31.2 & 31.2 & 62.5 & 15.6 & 15.6 & 31.2 & 31.2 & 62.5 \\
\hline Fusarium delphinoides & 250 & 125 & 62.5 & 62.5 & 31.2 & 62.5 & 62.5 & 125 & 250 \\
\hline Aspergillus nomius & 62.5 & 31.2 & 31.2 & 31.2 & 15.6 & 15.6 & 15.6 & 31.2 & 31.2 \\
\hline Aspergillus oryzae & 62.5 & 15.6 & 31.2 & 31.2 & 15.6 & 250 & 31.2 & 31.2 & 31.2 \\
\hline Aspergillus niger & 62.5 & 15.6 & 31.2 & 31.2 & 31.2 & 31.2 & 31.2 & 31.2 & 31.2 \\
\hline Aspergillus terrus & 125 & 31.2 & 31.2 & 62.5 & 31.2 & 15.6 & 31.2 & 31.2 & 62.5 \\
\hline Aspergillus nidulans & 62.5 & 15.6 & 31.2 & 62.5 & 15.6 & 31.2 & 15.6 & 15.6 & 31.2 \\
\hline Candida blankii & 62.5 & 62.5 & 62.5 & 62.5 & 62.5 & 62.5 & 62.5 & 62.5 & 62.5 \\
\hline Curvularia hawaiiensis & 125 & 62.5 & 62.5 & 125 & 31.2 & 15.6 & 31.2 & 31.2 & 31.2 \\
\hline Cochliobolus hawaiiensis & 62.5 & 15.6 & 15.6 & 250 & 31.2 & 62.5 & 62.5 & 62.5 & 250 \\
\hline Alternaria alternata & 125 & 31.2 & 31.2 & 62.5 & 31.2 & 31.2 & 31.2 & 62.5 & 31.2 \\
\hline Mucor circinelloides & 250 & 62.5 & 62.5 & 250 & 62.5 & 62.5 & 62.5 & 62.5 & 250 \\
\hline
\end{tabular}

Table 2: MIC values of different endophytic fungi against different tested strains in $\mu \mathrm{g}$.

\section{Time kill assay}

Time kill assay was performed over a period of $24 \mathrm{~h}$ with the $S$. typhi being exposed to $1 / 2 \mathrm{MIC}(0.78 \mathrm{mg} / \mathrm{ml})$, MIC $(1.56 \mathrm{mg} / \mathrm{ml})$ and $2 \times \mathrm{MIC}$ values $(3.12 \mathrm{mg} / \mathrm{ml})$ of ethyl acetate extract of Aspergillus nomius. A graph was plotted between the logarithmic number of $\mathrm{CFU} / \mathrm{ml}$ and time (Figure 1). Time kill assay showed $91.42 \%$ and $95.33 \%$ reduction at MIC and $2 \times$ MIC concentration respectively. Maximum reduction at MIC and $2 \times$ MIC concentrations was observed at $6 \mathrm{~h}$ of incubation for MIC value and at $24 \mathrm{~h}$ for $2 \times$ MIC concentration respectively. The $1 / 2 \mathrm{MIC}$ value reduced the growth up to $74.35 \%$ at $8 \mathrm{~h}$ of incubation. From the Figure 1 it was observed that effect of endophytic fungal extract at different concentrations was bacteriostatic. 
Page 5 of 6

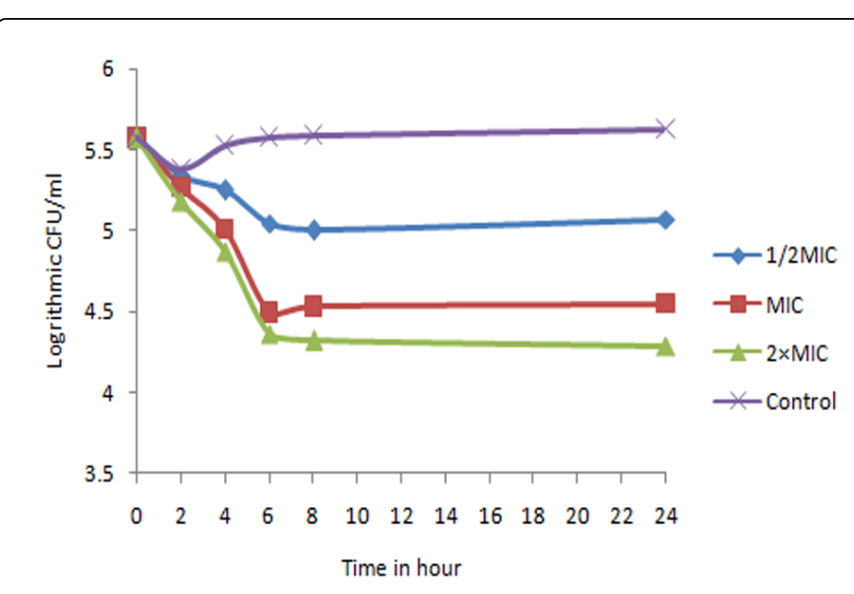

Figure 1: Represents the time kill assay graph of ethyl acetate extract of Aspergillus nomius against $S$. typhi.

\section{Discussion}

The antibacterial activity of the crude ethyl acetate extracts of various endophytic fungi was evaluated to test their antibacterial potential. Endophytic organism especially fungi have enormous potential to produce large range of bioactive secondary metabolites in order to protect their host plant against pathogens [22]. The antibiotic compounds massariphenone and ergosterol peroxide extracted from Verticillium sp. fungi associated with host plant Rehmannia glutinosa possess activity against the plant pathogen, Pyricularia oryzae P-2b [23]. Endophytic fungi also produce a variety compounds which have plant growth promoting activity [24], nematocidal activity [25] and also produce antifungal and antibacterial molecules [26]. So, the isolation and identification of endophytic fungi is of great importance. Yadav et al., studied that out of total 22 different endophytic fungi isolated from the $E$. jambolana (leaf, petiole and stem), 15 were showed significant antibacterial activities against the tested microorganisms [27]. Aharwal et al. [28] isolated 12 endophytic fungi from $C$. procera viz. Aspergillus niger, Aspergillus tamari, Aspergillus japonicus, Cladosporium herbarum, Alternaria alternata, Alternaria tenuissima, Drechslera nodulosa, Fusarium solani, Curvularia pallescens and Curvularia lunata. Out of which two were unidentified and the Fusarium solani extract showed most potent activity against $S$. epidermidis and E. coli. In the present study we have isolated 20 different fungal species; only three fungal species (Aspergillus niger, Alternaria alternata and Fusarium solani) are common to the above reported study.

Garcia et al. [29] reported that the ethyl acetate solvent system was most efficient method to extract endophytic fungi principle compounds. Highest antibacterial activity was reported in the ethyl acetate extract in comparison to other solvents as observed from previous studies on endophytic fungi species [30,31]. We have also used ethyl acetate as the extraction solvent. The results of this study correlate with the finding of other previous reports on antibacterial activity of endophytes [32,33]. The extracts of endophytic Aspergillus niger inhabiting Eugenia jambolana [27] and Aspergillus sp. isolated from Justicia adathoda [34] has been previously reported to displayed significant antimicrobial activities against tested bacteria and fungi strains. In the present study ethyl acetate extracts of Aspergillus nomius, Aspergillus oryzae, Aspergillus terrus and Fusarium solani and Penicillium citrinum showed significant antibacterial activity. Bugni et al. [35] concluded that Aspergillus genus is a major contributor of antimicrobial compound of fungal origin. Kalyanasundaram et al. [36] study showed the antibacterial activity of endophytic fungi against $S$. typhi, E. coli, P. mirabilis, Salmonella paratyphi, Vibrio cholera, Klebsiella oxytoca, $K$. pneumonia and $S$. aureus. These endophytic fungi may have quite good potential for utilization to inhibit the bacterial growth. In the present study endophytic fungal extracts are more effective against the Grampositive bacteria as compared to Gram-negative bacteria. This may be due to the reason that the Gram-negative bacteria have an additional outer membrane barrier as compared to the Gram-positive bacteria.

The time kill assay against the $S$. typhi indicates that the extracts of Aspergillus nomius were bacteriostatic because no sharp decrease in $\mathrm{CFU} / \mathrm{ml}$ was observed. Previously Sarbadhikary et al. [37] also reported the bacteriostatic effect of isolated fungi from leaves of Melastoma malabathricum L. on $S$. aureus and E. coli. In some case during the treatment it is advantageous to have drugs with bacteriostatic effect rather than the bactericidal action [38].

\section{Conclusion}

This study indicates that endophytic fungi isolated from different tissues of $C$. procera have pharmaceutical bioactive compounds with antibacterial potential. This may be due to the fact that endophytic microorganisms produce bioactive secondary metabolites. This study serves as first step needed to isolate and identify the pure bioactive compounds which are responsible for antibacterial activity of endophytic fungi.

\section{Conflict of Interest}

There is no conflict of interest between authors.

\section{Acknowledgement}

This research work was supported by a grant from DST [DSTINSPIRE, IF-140413] \& UGC-SAP [F.20/2012(SAP-II)].

\section{References}

1. Sharma D, Yadav JP (2017) An overview of phytotherapeutic approaches for the treatment of tuberculosis. Mini Rev Med Chem 17: 167-183.

2. Schulz B, Boyle C, Draeger S, Rommert AK, Krohn K (2002) Endophytic fungi: a source of novel biologically active secondary metabolites. Mycol Res 106: 996-1004.

3. Wali PP, Wali PR, Saikkonen K, Tuomi J (2013) Is the pathogenic ergot fungus a conditional defensive mutualist for its host grass? Plos One 8: e69249.

4. Upadhyay RS, Dubey NK, Raghuwanshi R (2014) Microbial Diversity and Biotechnology in Food Security. Springer.

5. Joshee S, Paulus BC, Park D, Johnston PR (2009) Diversity and distribution of fungal foliar endophytes in New Zealand Podocarpaceae. Mycol Res 113: 1003-1015.

6. Stierle A, Strobel G, Stierle D (1993) Taxol and taxane production by Taxomyces andreanae, an endophytic fungus of Pacific yew. Sci 260: 214-216.

7. Kumara PM, Zuehlke S, Priti V, Ramesha BT, Shweta S, et al. (2012) Fusarium proliferatum, an endophytic fungus from Dysoxylum binectariferum Hook.f, produces rohitukine, a chromane alkaloid possessing anti-cancer activity. Antonie van Leeuwenhoek 101: 323-329. 
8. Kusari S, Lamshoft M, Zuhlke S, Spiteller M (2008) An endophytic fungus from Hypericum perforatum that produces hypericin. J Nat Prod 71: 159-162.

9. Zhu D, Wang J, Zeng Q, Zhang Z, Yan R (2010) A novel endophytic Huperzine A producing fungus, Shiraia sp. Slf14, isolated from Huperzia serrata. J Appl Microbiol 109:1469-1478.

10. Kusari S, Pandey SP, Spiteller M (2013) Untapped mutualistic paradigms linking host plant and endophytic fungal production of similar bioactive secondary metabolites. Phytochem 91: 81-87.

11. http://www.cabi.org/isc/datasheet/16848.

12. Nenaah EG, Ahmed ME (2011) Antimicrobial activity of extracts and latex of Calotropis procera (Ait) and synergistic effect with reference antimicrobials. Res J Med Plant 5: 706-716.

13. Chaudhary P, Ahamad S, Khan NA (2017) A review on medicinal utility of Calotropis procera. World J Pharm Res 3: 335-342.

14. Parrotta JA (2001) Healing plants of peninsular India. CAB International Wallingford, UK.

15. Upadhyay R (2014) Ethnomedicinal, pharmaceutical and pesticidal uses of Calotropis procera (Aiton) (Family: Asclepiadaceae). Int J Green Pharm 8:135-146.

16. Eyberger AL, Dondapati R, Porter JR (2006) Endophyte fungal isolates from Podophyllum peltatum produces podophyllotoxin. J Nat Prod 69:1121-1124.

17. Kusari S, Lamshöft M, Spiteller M (2009) Aspergillus fumigatus Fresenius, an endophytic fungus from Juniperus communis L. Horstmann as a novel source of the anticancer pro-drug deoxypodophyllotoxin. J Appl Microbiol 107: 1019-1030.

18. Arnold AE, Maynard Z, Gilbert GS, Coley PD, Kursat TA (2000) Are tropical fungal endophytes hyperdiverse. Ecol Lett 3: 267-274.

19. Taye B, Giday M, Animut A, Seid J (2011) Antibacterial activities of selected medicinal plants in traditional treatment of human wounds in Ethiopia. Asian Pac J Trop Biomed 1: 370-375.

20. Sarker SD, Nahar L, Kumarasamy Y (2007) Microtitre plate-based antibacterial assay incorporating resazurin as an indicator of cell growth, and its application in the in vitro antibacterial screening of phytochemicals. Methods 42: 321-324.

21. Yadav A, Yadav M, Kumar S, Yadav JP (2015) Bactericidal effect of Acacia nilotica: In Vitro antibacterial and time kill kinetic studies. Int J Curr Res 7: 22289-22294.

22. Strobe GA (2003) Endophytes as sources of bioactive products. Microbes Infect 5: 535-544

23. You F, Han T, Wu JZ, Huang BK, Qin LP (2009) Antifungal secondary metabolites from endophytic Verticillium sp. Biochem Syst Ecol 37: 162-165.

24. Dai CC, Yu BY, Li X (2008) Screening of endophytic fungi that promote the growth of Euphorbia pekinensis. Afr J Biotechnol 7: 3505-3509.
25. Shahasi A, Dubois Y, Viljoen A, Nico L, Ragama P et al. (2006) In vitro antagonism of endophytic Fusarium oxysporum isolates against the burrowing nematode Radopholus similis. Nematol 8: 627-636.

26. Gunatilaka AAL (2006) Natural products from plant-associated microorganisms: distribution, structural diversity, bioactivity, and implications of their occurrence. J Nat Prod 69: 509-526.

27. Yadav M, Yadav A, Kumar S, Sharma D, Yadav JP (2014) Evaluation of in vitro antimicrobial potential of endophytic fungi isolated from Eugenia jambolana Lam. Int J Pharm Pharm Sci 6: 208-211.

28. Aharwal RP, Kumar S, Sandhu SS (2014) Isolation and antibacterial property of endophytic fungi isolated from Indian medicinal plant Calotropis procera (Linn.) R. Br. World J Pharm Pharm Sci 3: 678-691.

29. Garcia A, Rhoden SA, Bernardi-Wenzel J, Orlandelli RC, Azevedo JL, et al. (2012) Antimicrobial activity of crude extracts of endophytic fungi isolated from medicinal plant Sapindus saponaria L. J Appl Pharm Sci 2: 35-40.

30. Musavi SF, Balakrishnan RM (2014) A study on the antimicrobial potentials of an endophytic fungus Fusarium oxysporum NFX 06. J Med Bioeng 3: 162-166.

31. Verma VC, Kharwar RN, Strobel GA (2009) Chemical and functional diversity of natural products from plant associated endophytic fungi. Nat Prod Commun 4: 1511-1532.

32. Malhadas C, Malheiro R, Pereira JA, de Pinho PG, Baptista P (2017) Antimicrobial activity of endophytic fungi from olive tree leaves. World J Microbiol Biotechnol 33: 46.

33. Dissanayake RK, Ratnaweera $\mathrm{PB}$, Williams DE, Wijayarathne CD, Wijesundera RL, et al. (2016) Antimicrobial activities of endophytic fungi of the Sri Lankan aquatic plant Nymphaea nouchali and chaetoglobosin $\mathrm{A}$ and $\mathrm{C}$, produced by the endophytic fungus Chaetomium globosum. Mycology 7: 1-8.

34. Prabavathy D, Nachiyar CV (2012) Study on the antimicrobial activity of Aspergillus sp isolated from Justicia adathoda. Indian J Sci Technol 5: 3317-3320.

35. Bugni TS, Ireland CM (2004) Marine-derived fungi: a chemically and biologically diverse group of microorganisms. Nat Prod Rep 21: 143-163.

36. Kalyanasundaram I, Nagamuthu J, Muthukumaraswamy S (2015) Antimicrobial activity of endophytic fungi isolated and identified from salt marsh plant in Vellar Estuary. J Microbiol Antimicrob 7: 13-20.

37. Sarbadhikary SB, Pal B, Mandal NC (2016) Antimicrobial and antioxidant activities of two endophytic fungi isolated from Melastoma malabathricum L. leaves. Int J Curr Pharm Res. 8: 88-92.

38. Pankey GA, Sabath LD (2004) Clinical relevance of bacteriostatic versus bactericidal mechanisms of action in the treatment of Gram-positive bacterial infections. Clin Infect Dis 38: 864-870. 